UDC 613.6.02

DOI: $10.21668 /$ health.risk/2020.4.12.eng

Research article

\title{
PECULIARITIES IN ASSESSING OCCUPATIONAL HEALTH RISKS FOR WORKERS WHO ARE IN CONTACT WITH AEROSOLS CONTAINING FINE-DISPERSED DUST PARTICLES
}

\author{
M.F. Vil'k ${ }^{1}$, O.S. Sachkova ${ }^{1}$, L.A. Levanchuk ${ }^{2}$, E.O. Latynin ${ }^{1}$ \\ ${ }^{1}$ All-Russian Research Institute of Railway Hygiene, Bldg. 1, 1 Pakgauznoe shosse Str., Moscow, 125438, \\ Russian Federation \\ ${ }^{2}$ Emperor Alexander I St. Petersburg State Transport University, 9 Moskovskii Ave., Saint Petersburg, 190031, \\ Russian Federation
}

In Russia there is a system for standardizing and control over aerosols with predominantly fibrogenic effects and dust particles with different structure. But at the same time there are no hygienic standards for fine-dispersed dust contents in working area air and it makes hygienic assessment of working conditions more complicated and impedes use of risk assessment methodology.

Our research goal was to substantiate a concentration of aerosols containing fine-dispersed dust particles ( $\left.P M_{10} u P M_{2.5}\right)$ in working are air that were harmless for workers' health. It was done via applying a procedure for determining dust burden and using it when calculating health risks for workers.

We assessed dust content in working area air with focus on fine-dispersed dust particles $P M_{10} u P M_{2.5}$ with a dust measuring device «OMPN-10.0». Chemical structure of dust particles was determined with atomic absorption procedure. Results were estimated according to HS 2.2.5.3532-18. Dust burden was calculated according to State standard GOST R 54578-2011.

We established dependence between duration of working experience under exposure to fine-dispersed dust that was harmless for health and a value of excess in dust contents over the suggested concentration and work shift duration.

To assess health risk for workers caused by exposure to fine-dispersed dust particles taking their chemical structure into account, we determined reference concentrations for working area air; $0.1 \mathrm{mg} / \mathrm{m}^{3}$ for $P M_{10}$, and $0.055 \mathrm{mg} / \mathrm{m}^{3}$ for $P M_{2.5}$. Use of calculated concentrations allowed suggesting models for calculating harmless duration of working experience under exposure to dusts in concentrations higher than recommended ones. The results enable substantiating organizational activities aimed at workers' health preservation.

Key words: fine-dispersed dusts, working area air, health risk, aerosol with fibrogenic effects, work-related diseases, dust burden, reference concentration, working experience.

New research techniques aimed at examining occupational factors are being implemented into practice; it leads to changes in concepts regarding working conditions quality and nowadays health risk assessment methodology is required to assess them [1-3]. At present great attention is paid to such physical and chemical factors that pollute working area air as fine-dispersed dust aerosols $\left(\mathrm{PM}_{10}\right.$ and $\left.\mathrm{PM}_{2.5}\right)$.
In Russia there is a system for standardizing and control over aerosols with fibrogenic effects and dust particles with various structures. But still, there are no hygienic standards for fine-dispersed dust contents in working area air and it results in certain difficulties in performing hygienic assessment of working area air and makes it difficult to use health risk assessment methodology for well-grounded

(C) Vil'k M.F., Sachkova O.S., Levanchuk L.A., Latynin E.O., 2020

Mikhail F. Vil'k - Doctor of Medical Sciences, Professor, Director (e-mail: info@vniijg.ru; tel.: +7 (499) 153-27-37; ORCID: https://orcid.org/0000-0001-7103-2905).

Oksana S. Sachkova - Doctor of Technical Sciences, Associate professor, Leading researcher at the Laboratory for Communal Hygiene and Epidemiology (e-mail: vniijg@yandex.ru; tel.: +7 (926) 899-73-06; ORCID: https://orcid.org/0000000-3279-6560).

Leonid A. Levanchuk - Engineer at the testing center (e-mail: 576164@mail.ru; tel.: +7 (921) 327-22-85; ORCID: https://orcid.org/0000-0003-3576-3852).

Evgenii O. Latynin - Deputy Director (e-mail: jeckkk@yandex.ru; tel.: +7 (916) 624-29-96; ORCID: https://orcid.org/00000002-6822-521X). 
development of activities aimed at working conditions improvement [4-7].

Our research goal was to substantiate fine-dispersed dust particles $\left(\mathrm{PM}_{10}\right.$ and $\left.\mathrm{PM}_{2.5}\right)$ concentration in working area air that was harmless for workers' health; it was done basing on a procedure for determining dust burden and its subsequent use in calculating health risks for workers.

Data and methods. To quantitatively assess dust contents in working area air, we took AVA-3-180-001A aspirator and AFA-VP-10 filter. «OMPN-10.0» dust counter was applied to determine $\mathrm{PM}_{10}$ and $\mathrm{PM}_{2.5}$ concentrations. We determined chemical structure (measured mass fractions of metals compounds) of dust particles with atomic absorption spectroscopy. Results were assessed in accordance with HS 2.2.5.3532-18 ${ }^{1}$. Dust burden was calculated according to GOST R 54578-2011 $1^{2}$.

Results and discussion. Aerosols that occur due to technological operations involving use of items made from mineral cotton are poly-dispersed ones. They include ultra-fine dust $\mathrm{PM}_{2.5}$ with its Brownian motion being proportionate to gravitational settling: dust particles $\mathrm{PM}_{10}$ that settle in still air at a rate determined by their size and density according to Stokes' law; coarse dispersions (with their size exceeding $10 \mu \mathrm{m}$ ) that settle in still air at a growing rate [7].

Our research allowed determining concentrations of dust particles with different dispersity measured at different air humidity in working are air and at a different distance from a dust source when heat insulating operations were performed at a contraction site (tables 1 and 2).

Research results allowed establishing that growing air humidity made for lower dust particles concentrations and it should be noted that coarse dispersions concentrations went down more intensely. When a distance from a dust source was 35 meters, coarse dispersions concentration fell by 7 times; $\mathrm{PM}_{10}, 1.4$ times; and there were practically no changes in $\mathrm{PM}_{2.5}$ concentration. It is well in line with previously obtained data on dust contamination dispersity determining dust distribution in the air.

Having examined chemical structure of dust particles in working area air where heatinsulating operations were performed, we detected a wide range of various metals compounds (Tables 3 and 4).

Table 1

$\mathrm{PM}_{10}$ and $\mathrm{PM}_{2.5}$ concentrations at different working area air humidity at a distance from dust source being equal to 15 meters, $\mathrm{mg} / \mathrm{m}^{3}$, air flow speed being equal to $1.7 \pm 1.3 \mathrm{~m} / \mathrm{sec}, \mathrm{mg} / \mathrm{m}^{3}$

\begin{tabular}{|c|c|c|c|c|c|c|}
\hline \multirow{2}{*}{ Dust particles } & \multicolumn{7}{|c|}{ Air humidity, \% } \\
\cline { 2 - 7 } & 40 & 50 & 60 & 70 & 80 & 90 \\
\hline $\mathrm{PM}_{10}, \mathrm{mg} / \mathrm{m}^{3}$ & 1.26 & 1.17 & 1.02 & 1.02 & 0.96 & 0.9 \\
\hline $\mathrm{PM}_{2.5}, \mathrm{mg} / \mathrm{m}^{3}$ & 0.61 & 0.58 & 0.51 & 0.46 & 0.43 & 0.42 \\
\hline
\end{tabular}

Table 2

$\mathrm{PM}_{10}$ and $\mathrm{PM}_{2.5}$ concentrations on a construction site at different distances from a dust source and air humidity being $42 \pm 17 \%$, and air flow speed being equal to $1.5 \pm 1.2 \mathrm{~m} / \mathrm{sec}, \mathrm{mg} / \mathrm{m}^{3}$

\begin{tabular}{|c|c|c|c|c|c|c|c|}
\hline \multirow{2}{*}{ Dust particles } & \multicolumn{7}{|c|}{ Distance forma dust source, $\mathrm{m}$} \\
\cline { 2 - 8 } & 0 & 10 & 15 & 20 & 25 & 30 & 35 \\
\hline $\mathrm{PM}_{10}, \mathrm{mg} / \mathrm{m}^{3}$ & 1.83 & 1.68 & 1.59 & 1.62 & 1.56 & 1.35 & 1.35 \\
\hline $\mathrm{PM}_{2.5}, \mathrm{mg} / \mathrm{m}^{3}$ & 0.77 & 0.65 & 0.74 & 0.67 & 0.62 & 0.70 & 0.75 \\
\hline
\end{tabular}

\footnotetext{
${ }^{1}$ Hygienic standard HS 2.2.5.3532-18. Maximum permissible concentrations (MPC) of adverse substances in working area air. KODEKS: and electronic fund for legal and reference documentation. Available at: http://docs.cntd.ru/document/557235236 (03.06.2020) (in Russian).

${ }^{2}$ State Standard GOST R 54578-2011. Working area air. Aerosols with fibrogenic effects. Basic principles of hygienic control and exposure assessment. KODEKS: and electronic fund for legal and reference documentation. Available at: http://docs.cntd.ru/document/gost-r-54578-2011 (03.06.2020) (in Russian).
} 
Chemical structure of dust particles in working area air where heat-insulating operations were performed

\begin{tabular}{|c|c|c|c|c|c|c|c|c|c|c|c|}
\hline Compound & $\mathrm{SiO}_{2}$ & $\mathrm{Al}_{2} \mathrm{O}_{3}$ & $\mathrm{Fe}_{2} \mathrm{O}_{3}$ & $\mathrm{MgO}$ & $\mathrm{MnO}$ & $\mathrm{CaO}$ & $\mathrm{TiO}_{2}$ & $\mathrm{P}_{2} \mathrm{O}_{5}$ & $\mathrm{~K}_{2} \mathrm{O}$ & $\mathrm{Na}_{2} \mathrm{O}$ & others \\
\hline Share, $\%$ & 49 & 16 & 12 & 7 & $<1$ & 10 & 1 & $<1$ & $<1$ & 2 & $<3$ \\
\hline
\end{tabular}

Table 4

Metals contents in dust particles structure in working area air where heat-insulating works are performed $(\mathrm{mg} / \mathrm{kg})$

\begin{tabular}{|c|c|c|c|c|c|c|}
\hline Metal & $\mathrm{Cu}$ & $\mathrm{Zn}$ & $\mathrm{Cd}$ & $\mathrm{Ni}$ & $\mathrm{Fe}$ & $\mathrm{Mn}$ \\
\hline Contents, $\mathrm{M \Gamma} / \mathrm{Kmg} / \mathrm{kg \Gamma}$ & 50 & 133 & 15 & 59 & 1,780 & 70 \\
\hline
\end{tabular}

Fine-dispersed dust that occurs when heat-insulating operations are performed is a disintegration aerosol. Our data on quantitative structure of dust particles fit in with data obtained via previous research works [8-12].

Fine-dispersed dust particles are wellknown to cause respiratory and cardiovascular diseases and growth in mortality caused by such diseases under long-term intense exposure even in ambient air [13-20]. Consequently, in order to develop and give grounds for activities aimed at making occupational environment more favorable, it is necessary to assess health risks for workers; performing such an assessment may be a complicated task as there is no hygienic standard for finedispersed fractions in working area air. Since fine-dispersed dust particles, just as aerosols with fibrogenic effects, have adverse physical and chemical properties and exert negative impacts on a body, we applied a methodology for dust burden calculation ${ }^{1}$ for obtaining tentative reference $\mathrm{PM}_{10}$ и $\mathrm{PM}_{2.5}$ concentrations that could be then applied in assessing health risks for workers. There are rather limited data on effects produced by fine-dispersed dust fractions on a body. But still, there are data that average MPC of mineral cotton dust particles in working area air amounts to $0.5 \mathrm{mg} / \mathrm{m}^{3}$ over a shift. This concentration is equal to maximum single MPC for particulate matter that are nondifferentiated as per their structure (aerosols) in ambient air $\left(0.5 \mathrm{mg} / \mathrm{m}^{3}\right)$. Therefore, to perform rather tentative calculations, we took data from HS 2.1.6.3492-17 that fixes average daily MPC for $\mathrm{PM}_{10}$ at $0.06 \mathrm{mg} / \mathrm{m}^{3}$ and for $\mathrm{PM}_{2.5}$ at $0.035 \mathrm{mg} / \mathrm{m}^{3}$ as well as average annual MPC, $0.04 \mathrm{mg} / \mathrm{m}^{3}$ and $0.025 \mathrm{mg} / \mathrm{m}^{3}$ accordingly.

We applied the following basic formula for our calculations:

$$
\mathrm{DB}_{0}=\mathrm{MPC} \cdot \mathrm{N} \cdot \mathrm{T} \cdot \mathrm{Q},
$$

where

$\mathrm{DB}_{\mathrm{o}}$ is overall dust burden;

MPC is maximum permissible concentration of a specific fine-dispersed dust fraction;

$\mathrm{N}$ is a number of workdays per a calendar year;

$\mathrm{T}$ is maximum working experience duration, 30 years $^{3}$; $\left(m^{3}\right)^{4,5}$.

$\mathrm{Q}$ is lung ventilation volume over a shirt

${ }^{3}$ On Approval of Procedure for conducting a special assessment of working conditions, Classifier of adverse and (or) hazardous production factors, reporting form on a specific assessment of working conditions and instructions how to fill it in: The Order issued by the RF Ministry for labor and Social Protection on January 24, 2014 No. 33n. KODEKS: and electronic fund for legal and reference documentation. Available at: http://docs.cntd.ru/document/499072756 (03.06.2020) (in Russian).

${ }^{4}$ The Guide on assessment of occupational risks for workers' health. Organizational and methodical grounds, principles, and assessment criteria issued on June 24, 2003 No. 2.2.1766-03. KODEKS: and electronic fund for legal and reference documentation. Available at: http://docs.cntd.ru/document/901902053 (03.06.2020) (in Russian).

${ }^{5} \mathrm{R}$ 2.1.10.1920-04. The Guide on assessing population health risks under exposure to chemicals that pollute the environment. KODEKS: and electronic fund for legal and reference documentation. Available at: http://docs.cntd.ru/document/ 499072756 (03.06.2020) (in Russian). 
Various regulatory documents contain different data on lung ventilation volume when physical labor is performed. Given that, we took the following parameters for our calculation: lung ventilation volume amounted to $0.63 \mathrm{~m}^{3}$ per hour for time spent at home ( 8 hours); $0.88 \mathrm{~m}^{3}$ per hour for time spent elsewhere ( 8 hours); and $1.4 \mathrm{~m}^{3}$ per hour for time spent at a workplace. These parameters are usually applied when health risks are calculated ${ }^{3}$. Number of days per year is 365 ; number of workdays is 250, and days off, 115.

We took data on average daily MPC and average annual MPC in ambient air; exposure duration was taken as being equal to 24 hours, 7 days a week, and 70 years of life; our calculation allowed establishing average shift $\mathrm{PM}_{10}$ concentrations as being equal to $0.1 \mathrm{mg} / \mathrm{m}^{3}$; $\mathrm{PM}_{2.5}$ concentrations, $0.055 \mathrm{mg} / \mathrm{m}^{3}$, in working area air. These concentrations will not exceed control dust burden (occurring in actual living environment with actual average annual concentrations occurring in ambient air in urban settlements) even when working experience is 30 years and a working shift is 8 hours (40 hours a week). These concentrations can be used for assessing occupational health risks for workers who contact fine-dispersed dusts at their workplaces.

Suggested $\mathrm{PM}_{10}$ and $\mathrm{PM}_{2.5}$ concentrations obtained via our calculations are in line with reference doses used in determining health risks for population exposed to polluted ambient air. Thus, concentrations recommended for chronic exposure amount to $0.05 \mathrm{mg} / \mathrm{m}^{3}$ for $\mathrm{PM}_{10}$, and $0.015 \mathrm{mg} / \mathrm{m}^{3}$ for $\mathrm{PM}_{2.5}$. When determining risks caused by acute exposure, it is recommended to use $0.15 \mathrm{mg} / \mathrm{m}^{3}$ for $\mathrm{PM}_{10}$ and $0.065 \mathrm{mg} / \mathrm{m}^{3}$ for $\mathrm{PM}_{2.5}$.

These suggested reference concentrations for fine-dispersed dust particles occurring when items made of mineral fiber are used are truly relevant given essence of impacts exerted by fine-dispersed dust fraction on a body ${ }^{3}$ as well as data on a basic dust source at heat-insulating works being items made of mineral cotton (MPC is $2 / 0.5 \mathrm{mg} / \mathrm{m}^{3}$ ) and artificial mineral fiber with silicate glass-like structure (MPC is $/ 4 \mathrm{mg} / \mathrm{m}^{3}$ for coarse dispersions).

We applied up-to-date methodical approaches to assessing and predicting occupational risks to obtain model parameters of safe working experience duration for workers dealing with heat-insulating given different length of a work shift and different intensity of working area air pollution with finedispersed dust particles (Table 5 and Figure). These results are only preliminary and they should be confirmed with actual data on respiratory and cardiovascular diseases prevalence among workers who perform their work tasks under exposure to the examined adverse factors.

Models predicting harmless working experience for workers dealing with heat-insulating given different length of contacts with fine-dispersed dusts

\begin{tabular}{|c|c|}
\hline $\begin{array}{c}\text { Duration of a work } \\
\text { shift (hour) }\end{array}$ & Regression equation \\
\hline 8 & $y=-0.0043 x^{3}+0.0798 x^{2}-1.4478 x+31.225 ;$ \\
$R^{2}=0.9993$
\end{tabular}




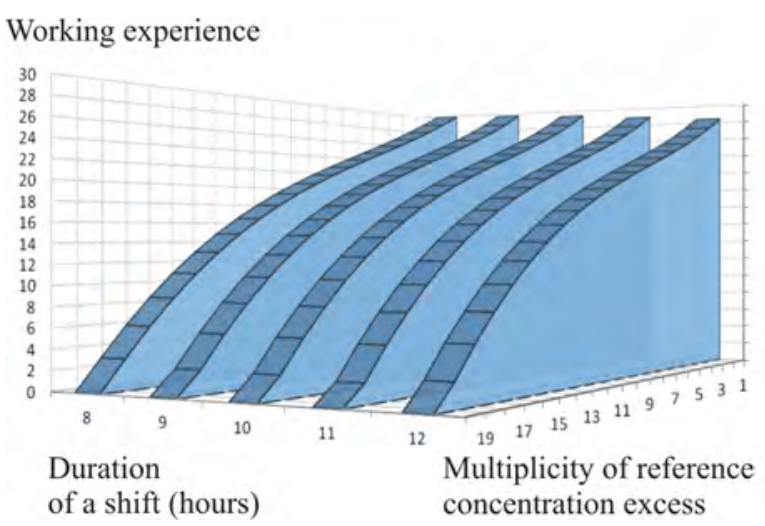

Figure. Duration of harmless working experience depending on multiplicity of reference $\mathrm{PM}_{10}$ concentration excess

Conclusion. At present hygienic assessment of working conditions necessarily involves assessing health risks for workers. But still, at present there are no standards for certain occupational factors that outline harmless exposure during the whole working experience (30 years) that has been extended due to an increase in retirement age. We determined tentative reference $\mathrm{PM}_{10}$ and $\mathrm{PM}_{2.5}$ concentrations in working are air that were equal to $0.1 \mathrm{mg} / \mathrm{m}^{3}$ and $0,055 \mathrm{mg} / \mathrm{m}^{3}$ accordingly. These concentrations were determined taking chemical structure of particles into account and basing on control dust burden calculation; therefore, they can be used in assessing health risks for workers dealing with heat-insulating and contacting finedispersed dust particles. Exposure to finedispersed particles in the given tentative concentrations at a workplace during 30-year working experience and a work shift being 8 hours a day does not increase overall dust burden on a body. These concentrations can be determined without any changes in a procedure for establishing MPC for aerosols with fibrogenic effects and they can be used for preliminary assessment of health risks for workers who are exposed to fine-dispersed dusts at their workplaces. Use of calculated tentative reference concentrations allowed us to suggest models for calculating harmless working experience duration given that the recommended dust parameters (MPC) are violated. Bearing in mind that there are no established MPC for fine-dispersed mineral cotton dust fractions in working area air, we can conclude that our research results allow substantiating organizational activities aimed at workers' health preservation.

Funding. The research was not granted any sponsor support.

Conflict of interests. The authors declare there is no any conflict of interests.

\section{References}

1. Health risk analysis in the strategy of state social and economical development: monography. In: G.G. Onishchenko, N.V. Zaitseva eds. Perm', Izdatel'stvo Permskogo natsional'nogo issledovatel'skogo politekhnicheskogo universiteta Publ., 2014, 738 p. (in Russian).

2. Bukhtiyarov I.V., Bobrov A.F., Denisov E.I., Eremin A.L., Kur'erov N.N., Losik T.K., Pochtareva E.S., Prokopenko L.V. [et al.]. Occupational risk assessment methods and their information support. Gigiena i sanitariya, 2019, vol. 98, no. 12, pp. 1327-1330 (in Russian).

3. Zagorodnov S.Yu., May I.V., Kokoulina A.A. Fine-disperse particles $\left(\mathrm{PM}_{2.5}\right.$ and $\left.\mathrm{PM}_{10}\right)$ in atmospheric air of a large industrial region: issues related to monitoring and standardization of suspended particles in industrial emissions. Gigiena i sanitariya, 2019, vol. 98, no. 2, pp. 142-147 (in Russian).

4. Zemlyanova M.A., Zaitseva N.V., Ignatova A.M., Stepankov M.S. Estimation of the response of respiratory tracts to a single intra-tracheal introduction of nano- and micro-sized particles of aluminum oxide. Gigiena i sanitariya, 2019, vol. 98, no. 2, pp. 196-202 (in Russian).

5. Kopytenkova O.I., Levanchuk A.V., Tursunov Z.Sh. Health risk assessment for exposure to fine dust in production conditions. Meditsina truda i promyshlennaya ekologiya, 2019, vol. 59, no. 8, pp. 458-462 (in Russian).

6. Kopytenkova O.I., Tursunov Z.Sh., Levanchuk A.V. Ispol'zovanie metodologii otsenki riska zdorov'yu dlya gigienicheskoi kharakteristiki uslovii truda $\mathrm{v}$ stroitel'noi otrasli [Use of risk assessment methodology for hygienic characteristics of working conditions in construction]. Zdorov'e $i$ 
bezopasnost' na rabochem meste: materialy III mezhdunarodnogo nauchno-prakticheskogo foruma. Novopolotsk-Polotsk, 2019, pp. 152-156 (in Russian).

7. Kopytenkova O.I., Tursunov Z.Sh. Risk assessment and directions improving of labor protection in construction when using mineral wools. Internet-zhurnal Naukovedenie, 2013, vol. 14, no. 1, pp. 17 (in Russian).

8. Strelyaeva A.B., Marinin N.A., Azarov A.V. The importance of disperse structure of dust in technological processes. Internet-vestnik VolgGASU, 2013, vol. 28, no. 3, pp. 1-4 (in Russian).

9. Burnett R.T., Cakmak S., Brook J.R., Krewski D. The role of particulate size and chemistry in the association between summertime ambient air pollution and hospitalization for cardiorespiratory disease. Environ. Health Perspect, 1997, vol. 105, no. 6, pp. 614-620. DOI: 10.1289/ehp.97105614

10. Pope C.A. Epidemiology of fine particulate air pollution and human health: biologic mechanisms and who's at risk. Environmental Health Perspectives, 2000, vol. 108, no. 4, pp. 713-723. DOI: $10.1289 /$ ehp.108-1637679

11. Health effects of particulate matter. Policy implications for countries in eastern Europe, Caucasus and central Asia. World health organization, 2013, 20 p. (in Russian).

12. Nemmar A., Hoylaerts M.F., Hoet P.H.M., Nemery B. Possible mechanisms of the cardiovascular effects of inhaled particles: systemic translocation and prothrombotic effects. Toxicology Letters, 2004, vol. 149, no. 1, pp. 243-253. DOI: 10.1016/j.toxlet.2003.12.061

13. Akinlade G.O., Olaniyi H.B., Olise F.S., Owoade O.K., Almeida S.M., Almeida-Silva M., Hopke P.K. Spatial and temporal variations of the particulate size distribution and chemical composition over Ibadan, Nigeria. Environmental Monitoring and Assessment, 2015, vol. 187, no. 8, pp. 544. DOI: $10.1007 / \mathrm{s} 10661-015-4755-4$

14. Anderson J.O., Thundiyil J.G., Stolbach A. Clearing the Air: A Review of the Effects of Particulate Matter Air Pollution on Human Health. Journal of Medical Toxicology, 2012, vol. 8, no. 2, pp. 166-175. DOI: $10.1007 / \mathrm{s} 13181-011-0203-1$

15. Kim K.-H., Kabir E., Kabir S. A review on the human health impact of airborne particulate matter. Environment International, 2015, no. 74, pp. 136-143. DOI: 10.1016/j.envint.2014.10.005

16. Leung A.O.W., Duzgoren-Aydin N.S., Cheung K.C., Wong M.H. Heavy Metals Concentrations of Surface Dust from e-Waste Recycling and Its Human Health Implications in Southeast China. Environmental science \& Technology, 2008, vol. 42, no. 7, pp. 2674-2680. DOI: 10.1021/es071873x

17. Fang W., Yang Y., XuZh. $\mathrm{PM}_{10}$ and $\mathrm{PM}_{2,5}$ and Health Risk Assessment for Heavy Metals in a Typical Factory for Cathode Ray Tube Television Recycling. Environmental science \& Technology, 2013, vol. 47, no. 21, pp. 12469-12476. DOI: 10.1021/es4026613

18. Tainio M., Tuomisto J., Karvosenoja N., Kupiainen K., Porvari P., Sofiev M., Karppinen A., Kukkonen J. Uncertainty in health risks due to anthropogenic primary fine particulate matter from different source types in Finland. Atmospheric Environment, 2010, vol. 44, no. 17, pp. 2125-2132. DOI: $10.1016 /$ j.atmosenv.2010.02.036

19. Schindler C., Keidel D., Gerbase M.W., Zemp E., Bettschart R., Brändli O., Brutsche M.H., Burdet L. [et al.]. Improvements in PM10 Exposure and Reduced Rates of Respiratory Symptoms in a Cohort of Swiss Adults (SAPALDIA). American Journal of Respiratory and Critical Care Medicine, 2009, vol. 1, no. 179 (7), pp. 579-587. DOI: 10.1164/rccm.200803-388OC

20. Valeeva E.T., Galimova R.R., Kopytenkova O.I., Distanova A.A. Justification of approaches to the prevention of occupational and work-related diseases in workers during production and use of artificial mineral fibers. Sanitarnyi vrach, 2020, no. 1, pp. 32-40 (in Russian).

Vil'k M.F., Sachkova O.S., Levanchuk L.A., Latynin E.O. Peculiarities in assessing occupational health risks for workers who are in contact with aerosols containing fine-dispersed dust particles. Health Risk Analysis, 2020, no. 4, pp. 107-112. DOI: 10.21668/health.risk/2020.4.12.eng

Received: 26.06.2020

Accepted: 11.11 .2020

Published: 30.12 .2020 